\title{
Romanos e Não-Romanos: o nascimento da Christianitas
}

Gabriel Irinei Covalchuk ${ }^{1}$

Resumo: No presente artigo, buscamos mostrar a relação entre romanos e não romanos e como elas se travaram até o nascimento da Christianitas. Partimos de uma discussão de Momigliano, sobre a recusa de certas práticas que eram consideradas profanas pelos judeus e como esse mesmo método foi adotado pelos cristãos nascentes do primeiro século. Analisaremosas leis de como comportar-se em território não Cristão pregado por Bardaisane uma moral pregada por Tertuliano, também abordando o desenvolvimento da prática cristã e sua legitimação. Encaminhando para o fimdessa primeira 'etapa',abordamos o nascimento da Cristandade, percebemosque ela foi desenvolvendo-se durante o governo de Constantino Magnono século IV, concluindo assim, que a demonstração de seu papel ativo e participante na política do Império Romano, mudou um conceito chave, ou seja, antes da ascensão cristã, ser romano era não ser cristão, com a Christianitas legitimada, ser romano é ser um genuíno cristão.

Palavras-Chave: Cristandade; Constantino; Romanos.

Resumen: En el presente artículo, buscamos mostrar la relación entre romanos y no romanos y cómo se trabaron hasta el nacimiento de Christianitas. Partimos de una discusión de Momigliano, sobre el rechazo de ciertas prácticas que eran consideradas profanas por los judíos y cómo ese mismo método fue adoptado por los cristianos nacientes del primer siglo. Analizamos las leyes de cómo comportarse en territorio no cristiano predicado por Bardaisan y una moral predicada por Tertuliano, también abordando el desarrollo de la práctica cristiana y su legitimación. Encaminándose para el final de esa primera etapa, con el nacimiento de la Cristiandad, y cómo se desarrolló durante el gobierno de Constantino en el siglo IV, concluyendo así, con la demostración de su papel activo y participante en la política del Imperio

${ }^{1}$ Gabriel I. Covalchuké graduado em História pela UNESPAR (Universidade Estadual da Paraná), Campus de União da Vitória-PR. Foi bolsista de Iniciação Científica da Fundação Araucária de Apoio ao Desenvolvimento Científico e Tecnológico, vinculado ao projeto Linguagens e Tecnologias no Ensino de História, desenvolvido pelo LAPHIS sob orientação do professor Everton Carlos Crema e da professora Dulceli de Lourdes Estacheski Tonet. Atualmente é vinculado ao Núcleo de Estudos Escriniumque visa propor um diálogo interdisciplinar (História, Filosofia e Literatura) em pesquisas que detém o recorte temporal no período Antigo, Tardo-Antigo e Medieval.

Revista Vernáculo n. ${ }^{\circ} 43$ - primeiro semestre/2019

ISSN 2317-4021 
Romano, cambiando un concepto clave, es decir, antes de la ascensión cristiana, ser romano era no ser cristiano, con la Christianitaslegitimada, ser romano es ser un genuino Cristiano.

Palabra Clave: Cristianismo; Constantino; Romanos.

De acordo com Momigliano, o povo romano passou por algumasinfluências, principalmente do helenismo e o judaísmo, no último podemos destacara ideologia do Deus único quecerca todas as bases, tanto do povo judeu quanto dos cristãos. Podemos perceber que esse 'etnocentrismo’em volta de sua própria cultura predominou sempre o imaginário do povo monoteísta, como mostra o autor, "o repúdio ao helenismo em Jerusalém era sem dúvida uma reafirmação da fidelidade da comunidade judia ao Deus de Abraão, Isaac e Jacó, mas era ao mesmo tempo o resultado de muitas escolhas individuais ${ }^{2}$ ".

Destaca ainda o autor, o uso do Antigo Testamento para explicar os moldes da crença monoteísta, mas também podemos utilizar-se do 'Novo'3, para compreendermos a crença da fé cristã. O historiador por sua vez, não pode nutrir certas ideias preconcebidas e estereotipadas em espécie de fonte antes que o mesmo passe pelo crivo da crítica científica, percebemos, que tanto o Antigo quanto o Novo Testamento passaram por esse processo, e até hoje 'sofrem' diversos ataques. Nesse sentido podemos usar ambos os escritos para explicar a ideologia cristã desde o processo judaico e sua total influência na comunidade nascente

\footnotetext{
${ }^{2}$ MOMIGLIANO, A. Os limites da Helenização: a interação cultural das civilizações grega, romana, céltica, judaica e persa. Rio de Janeiro, Jorge Zahar Editor, 1991, p.92. ${ }^{3}$ Todas as citações bíblicas terão como base a Bíblia de Jerusalém, publicada pela editora Paulus em 2002.
}

Revista Vernáculo n. ${ }^{\circ} 43$ - primeiro semestre/2019

ISSN 2317-4021 
no primeiro século, passando por Bardaisan, Tertuliano, até chegar ao Imperador Constantino.

Como se sabe, o Cristianismo surgiu na Palestina no tempo Herodes, iniciado por um processo de concessão a liberdade religiosa dos judeus, e provavelmente no final do seu reino, mais precisamente em 6 a.C. que Jesus nasceu ${ }^{4}$. Na medida do possível ${ }^{5}$, o povo judeu convertido aos passos do 'messias' tornaram seguidores praticantes da nova religião ignorando os deuses romanos e tinham apenas certo respeito diante do imperador (não adotavam o culto ao mesmo). No entanto, dentro da sua cultura as regras eram mais restritas, quando "burlados" certos costumes presentes na mesma', como a circuncisão ${ }^{7} \mathrm{e}$ o sabbath ${ }^{8}$ tinham o "infrator" considerado profano e impuro, ou seja, reprovação do que não era Divino. Podemos ainda pensar essa

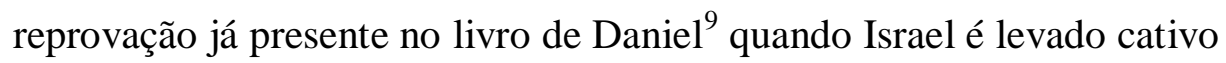
a Babilônia.

A prática dos judeusestava em apenas de respeitar o imperador Babilônico no século VI a.C, mas não realizar as pratica ordenadas pelo mesmo, fato esse que também fora seguidas pelos cristãos do primeiro

4 Diferenças de datas ocorrem devido ao calendário da época ser o Juliano e atualmente usamos o gregoriano.

${ }^{5}$ Pois envolvia toda uma cultura de época, e o individuo deveria conseguir suportar a rejeição da família e da sociedade judaica.

${ }^{6} \mathrm{O}$ período de entendimento sobre dispensação da graça (lei versus graça), só será explicada mais tarde com o apóstolo Paulo.

${ }^{7} \mathrm{Gn}, 17,10-14$.

${ }^{8} \hat{\mathrm{E} x}, 16,23-26$.

${ }^{9}$ Dn, $1,1-14$

Revista Vernáculo n. ${ }^{\circ} 43$ - primeiro semestre/2019

ISSN 2317-4021 
século d.C, pois os mesmos entendiam que a adoração (latreia ${ }^{10}$ ), deveria ser dada apenas a Deus. É lógico que o imperador não iria aceitar esse ato revoltoso, e logo decretou uma série de castigos aos recém praticantes da nova religião.

A primeira perseguição aos cristãos aparece no livro de Atos dos Apóstolos retratado na figura de Saulo de Tarso ${ }^{11}$. No ano de 64 d.C. Quando Nero ${ }^{12}$ governava o Império Romano, campanhas de perseguição aos cristãos eram frequentes, algumas eram mais amplas, mas a maior parte delas concentrava-se em locais específicos, sob o

${ }^{10} \Lambda \alpha \tau \rho \varepsilon i ́ \alpha$, aৎ (†): 1 serviço; serviço de assalariados; serviço de mercenário 2 culto de um deus; adoração 3 cuidados com o corpo ou a alma. ( $\Lambda \alpha \tau \rho$ cív $\omega)$. MALHADAS, D.; DEZOTTI, M. C. C.; NEVES, M. H. M. (coord.). Dicionário grego-português Vol. 3. Cotia: Ateliê Editorial. 2006, p. 114.

${ }^{11}$ A figura de Saulo de Tarso aparece na Bíblia pela primeira vez no livro de Atos dos Apóstolos no capitulo 7, mais precisamente no versículo 58 quando ele consentiu no apedrejamento de Estevão que pregava a Jesus como o esperado messias. No capítulo 8 do mesmo livro mostra Saulo assolando a igreja, entrando nas casas, arrastando homens e mulheres e os colocava na prisão, no capítulo 9 ele pede carta ao sumo sacerdote pedindo a permissão para prender todos que encontrasse professando a fé cristã.

${ }^{12}$ Segundo Balsdon (1968, p.195), Nero colocou fogo em Roma (fato que não se sustenta mais historicamente) e culpou os Cristãos de terem feito isso, Pedro e Paulo, pais da igreja, provavelmente foram incluídos entre os mortos desse episodio. No entantopara Daniel-Rops (1956, p. 180) a afirmação como essa não seria procedente, afinal Roma era uma "cidade sobrepovoada, onde numerosas habitações amontoadas e construídas de madeira eram pasto fácil das chamas". Como afirmam Corsi e Bottazzini (2011, p. 165) '...muito provavelmente o incêndio tenha começado de forma acidental, no entanto a mente do vulgo procurava de qualquer maneira um responsável, afinal não pode haver "acaso" onde os deuses governam'. No livro XV dos Annales de Tácito (XV, 38-44), podemos afirmar que o imperador apenas forjou culpados, mas que o mesmo no momento do incêndio se encontrava em Antium, retornando a cidade somente quando o fogo aproximava-se do seu palácio, mesmo assim, ele montou prédios improvisados para receber a multidão carente e comestíveis foram embarcados emÓstia e municípios vizinhos, e o preço do grão foi reduzido a três sestércios.

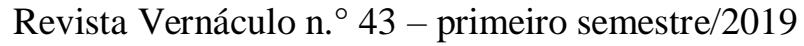

ISSN 2317-4021 
comando de governadores de províncias, sendo o número de cristãos presos incalculáveis. Os crentes desafiados que se recusavam a renunciar ao seu Deus, aceitar o culto ao imperador e as práticas da religião romana eram cruelmente torturados em público, embora possa parecer anacrônico, parece que o sentimento "bardaisiano"13 já pairava sobre eles. Sua crença sem sombra de dúvida era de serem cuidados e protegidos por Jesus, sem esse ideal, as religiões cristãs não se disseminaria tanto.

\section{Processo de ascensão do cristianismo}

Segundo Peter Brown o processo de ascensão do Cristianismo deve ser analisada a partir de uma figura central e culta dos reis da cidade de Osroene, chamado Bardaisan ${ }^{14}$ (154 d.C - 222). Tal figura no início do século III na cidade de Edessa produziu um tratado sobre o determinismo e o livre-arbítrio. Edessa localizava entre duas cidades de forte influência cultural, Roma e Pérsia, mas não era miscigenada intelectualmente.

Bardaisan além de cortesão era cristão e no seu tratado, Livro das Leis das Nações afirmava que "qualquer que seja o local onde se encontrem, as leis locais nunca os poderão obrigar a esquecer da lei do

${ }^{13}$ Que será explicado posteriormente.

${ }^{14}$ Conforme afir;ma o professor da UERJ (Universidade Estadual do Rio Janeiro), André Bueno - "De fato, a reconstituição da vida de Bardasano é bastante dificultada pela escassez de fontes, devendo-se recorrer, em grande parte, ao que restou de sua obra". BUENO, André. Etnografias religiosas no livro das leis dos países, de Bardasano de Edessa. NEARCO - Revista Eletrônica de Antiguidade, Ano VIII, Número II, Rio de Janeiro, 2015. p. 37-38.

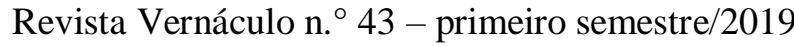

ISSN 2317-4021 
Messias", ou seja, um dos principio da Christianitas. Mesmo depois de sua morte em 222 d.C. o seu ideal de mudança é seguido por muitos, pois como afirma Brown "qualquer livro sobre o papel do cristianismo na formação da Europa Ocidental entre 200 e 800 deve começar por uma visão tão vasta como a de Bardaisan"15.

Podemos afirmar que assim como Agostinho de Hipona ${ }^{16}$, o siríaco também teve um passado ligado ao "paganismo" ", sendo assim, demonstrar o livre arbítrio justificavatambém seus "erros" anteriores; além disso, Bardaisan quando adepto da astrologia babilônica, entendia que os corpos celestes influenciavam nos movimentos sociais e individuais, "em escala macro-cósmica, os corpos celestes influenciaram as noções gerais de lei, ordem e costume de uma civilização; e em escala micro-cósmica, elas determinam o caráter e as tendências do indivíduos"18. Após sua conversão ao cristianismo, por conta de sua própria experiência, entende que converter-se à outra

${ }^{15}$ BROWN, Peter. A ascensão do Cristianismo no Ocidente. Lisboa: Editorial Presença, 1999, p. 22.

${ }^{16}$ Que mais tarde escrevera o De libero arbítrio.

${ }^{17}$ Só lembrado No final do século IV que o termo paganuscomeçou a ser utilizado como estatuto marginal do politeísmo.Isidoro de Sevilha. Etym. VIII, 10,1: PaganiexpaganisAtheniensiumdicti, ubiexorti sunt. Ibienim in locisagrestibusetpagisgentileslucosidolaquestatuerunt, et a tali initio vocabulumpaganisortiti sunt, ou seja, "o nome pagão deriva das aldeias atenienses de onde tive seu início. Naqueles lugares agrestes e naqueles pagos estabeleceram os gentis bosques sagrados e erigiram seus ídolos, e por ser tal sua origem receberam este nome de pagãos". (Tradução feita pelo professor Dr. Everton Grein)

${ }^{18}$ BUENO, André., op. cit., p. 38.

Revista Vernáculo n. ${ }^{\circ} 43$ - primeiro semestre/2019

ISSN 2317-4021 
religião revela a falha da astrologia ${ }^{19}$ e mostra o individuo escolhendo os seus próprios destinos, ou seja, livre arbítrio.

\section{Moral cristã}

Partindo de um processo de formação do seguimento e moral cristã, analisaremos um homem chamado Tertuliano que nasceu em Cartago por volta do ano de 155 d.C., de família abastada exercia sua profissão de advogado quando no ano de 193 converteu-se ao cristianismo e assim passou a ter um papel importantíssimo na construção da identidade cristã. Analisando o Apologeticum de Tertuliano, escrito no ano 197 e dirigida aos governantes do Império Romano, percebemos que o autor deixa claro a perseguição contra os cristãos.

Se, sendo constituídos para a administração da justiça em vosso elevado Tribunal, sob os olhares de todos os cidadãos, ocupando ali a mais elevada posição no Estado, vós não podeis abertamente inquirir e perscrutar, diante de todo o mundo, a verdade real com respeito às perseguições feitas contra os Cristãos. ${ }^{20}$

Tertuliano ressalta em quase todos os capítulos que o termo cristão era sinônimo de ódio e ignorância, e contrariando as Leis das XII Tábuas, mostrava um fato que ocorre praticamente em todos os

\footnotetext{
${ }^{19}$ Bardaisan tentava mostrar uma possível falha na astrologia para converter seus adeptos ao cristianismo, assim como os filósofos cristãos dos primeiros séculos alegaram que o $\lambda$ ó ${ }^{\circ}$ (logos) grego era o Messias, para convertê-los.

20 TERTULIANO. Apologia. Trad. José Fernandes Vidal/ Luiz Fernando KarpsPasquotto. Disponível em: www.tertullian.org/brazilian/apologia.html, acesso dia 24/06/2017 ás 23:09, capítulo I p.3.
}

Revista Vernáculo n. ${ }^{\circ} 43$ - primeiro semestre/2019

ISSN 2317-4021 
períodos jurídicos, distância entre a teoria e a prática, “de fato, é contra a lei condenar alguém sem defesa e sem audiência. Somente os cristãos são proibidos de dizerem algo em sua defesa, na salvaguarda da verdade, para ajudar ao juiz numa decisão de direito" ${ }^{21}$. Embora o Império pregasse à ideia que todos tinham o direito a defesa, esse fato era ignorado quando se tratava em defesa cristã.

Assim como Nero acusou os cristãos de terem colocado fogo em Roma $^{22}$, os governantes do século II-III acusavam os cristãos de práticas "desumanas", como sacrifícios humanos em ações secretas, Tertuliano mostra que tais práticas eram realizadas pelos não cristãos/romanos/humanitas:

Eis como posso refutar tais acusações: mostrar-vos-ei práticas que vigoram entre vós, em parte abertamente, em parte secretamente, que vos levaram, talvez, a nos acusar de coisas semelhantes. Os meninos eram sacrificados abertamente na África a Saturno até o proconsulado de Tibério, que expôs à vista do público os seus sacerdotes crucificados nas árvores sagradas, que lançavam sombras sobre seus templos - tantas eram as cruzes nas quais a justiça exigida aplicou o castigo por seus crimes, como os nossos soldados podem ainda testemunhar, tendo sido, de fato, esta uma obra daquele Procônsul. Até presentemente aquele criminoso culto continua a ser feito, secretamente. ${ }^{23}$

Mas qual explicação se daria ao fato de os governos romanos terem tanto ódio e utilizar-se da violência para disseminar os cristãos? Essa resposta ao que nos parece fica clara no capítulo $X$; a recusa da

${ }^{21} I d$.,Ibid., capítulo II p.4.

${ }^{22}$ Segundo a narrativa de Tácito.

${ }^{23} I d$., Ibid.,capítulo IX, p.7.

Revista Vernáculo n. ${ }^{\circ} 43$ - primeiro semestre/2019

ISSN 2317-4021 
adoração ou sacríficos da religião romana, o que pelos imperadores era considerado uma total traição ao Império. Na visão dos governantes os cristãos causavam divisão e estavam apenas buscando seus próprios interesses.

\begin{abstract}
Vós nos acusais: "Não adorais os deuses e não ofereceis sacrifícios aos imperadores". Sim, não oferecemos sacrifícios a outros pela mesma razão pela qual não os oferecemos a nós mesmos, ou seja, porque vossos deuses não são, de modo algum, referenciais para nossa adoração. Por isso, somos acusados de sacrilégio e de traição. Esse é o principal fundamento de vossa perseguição contra nós. Sim, é toda a razão de nossa ofensa. É digna, então, de exame a respeito, se não forem nossos juízes a prevenção e a injustiça, pois a prevenção não leva a sério descobrir a verdade, e a injustiça a rejeita simples e totalmente. ${ }^{24}$
\end{abstract}

Essa moral que esta sendo instaurada por Tertuliano ${ }^{25}$ mostra como estava crescendo o ideal da Christianitas, que buscava diálogo com a política. Os cristãos diferentes das acusações não eram vaidosos, mas honravam o imperador com suas orações e não com sacrifícios, não eram entregues a bebida e nem libertinos, andando com prudência e com boa consciência, tendo em si a frase paulina "tudo me é permitido, mas nem tudo convém. Tudo me é permitido, mas não me deixarei escravizar por coisa alguma". ${ }^{26}$

${ }^{24} I d$., Ibid., capítulo X, p. 9.

${ }^{25}$ Lógico que não podemos esquecer do braço intelectual filosófico produzido nos primeiros séculos por Justino de Roma, Clemente de Alexandria, Orígenes, etc.

${ }^{26} 1$ Co., 6,12 .

Revista Vernáculo n. ${ }^{\circ} 43$ - primeiro semestre/2019

ISSN $2317-4021$ 


\section{Diocleciano X Christianitas}

Mesmo com a defesa de fé abordada anteriormente, as perseguições vão oscilando entre mais e menos drásticas, até chegarmos ao entre o ano 238 e 270 . Nesse período o Império romano enfrentava as repetidas derrotas de grandes exércitos, a fragmentação política e as bancarrotas, no entanto, em 284, Diocleciano assumiu o poder e garantiu uma administração dividida, colocando coimperadores, que ficou conhecida como Tetrarquia. O imperador vendo a impossibilidade de governar sozinho todo o Império, formula uma ordem de dividir o mesmoprimeiramente em duas partes, futuramente em quatro ${ }^{27}$, uma divisão que tinha por objetivo garantir a unidade territorial, e a eficiência e integridade do poder imperial.

When Diocletian rose to the imperial dignity after the assassination of Numerian and after rapidly ridding himself of Carinus, he possibly adopted and certainly appointed as Caesar and shortly after as Augustus Maximian, an old comrade in arms and like himself a man of humble origins, whom he sent to control the west. The new system of government was thus diarchic and as such had precedents in the history of the third century. But what was now being given some form of official sanction was a territorial partition of duties between the two Augusti. A few years later, in293, two other soldiers, ConstantiusChlorus and

${ }^{27}$ OLIVEIRA, W. F. A Antiguidade Tardia. São Paulo: Ática,1990, p.32: ' A partir de então passaram a existir quatro imperadores, dois deles portando o título de Augustus, e os dois outros Césares, cabendo a esse últimos substituírem os Augustus, em caso de sua morte ou após decorridos vinte anos de seus governos".

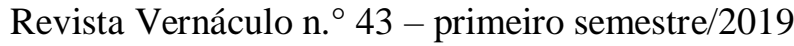

ISSN $2317-4021$ 
Maximianus Galerius, were raised to the purple as Caesars. The diarchywastransformedinto a tetrarchy. ${ }^{28}$

As palavras de ordem da época eram repatio e renovatio, tanto que Diocleciano manteve praticamente sem alteração a carga fiscal, o que permaneceu assim até o fim do Império Romano. Seu governo tinha uma boa estrutura econômica, mas ainda possuía cristãos e não cristãos em total desigualdade. A religião romana que estava perdendo 'fiéis' continuava ligada ao senso comum, o que considerava obvia a existência de muitos deuses, sendo alguns mais importantes que outros; e cada um exigia uma religio ${ }^{29}$ diferente.

Diocleciano não toleraria o cristianismo em seu território, a dificuldade de mudança do imperador passava do lado econômico e refletia no religioso, pois declarava que a antiga religião não deve ser censurada por uma nova, pois nada pode ser mais criminoso do que inverter aquilo que os antepassados definiram de uma vez por todas, as coisas que guardam e mantêm um lugar e um curso por todos reconhecidos.

Para manter essa estrutura proposta por Diocleciano e percebendo à afronta do cristianismo no ano de 303 d.C., instaurou uma medida contra os Cristãos, que ficou historicamente conhecida como "A Grande

${ }^{28}$ Bowman, A. K. Diocletian and the first tetrarchy, a.d. 284-305. In: The Cambridge Ancient History, The Crisis of Empire, a.d. 193-337. London: Cambridge University Press, 2008, p.170.

${ }^{29}$ A forma adequada de veneração de cada deus, o que consistia em sacrifícios habituais a favor dos nossos senhores, os imperadores, e das suas vitórias para cada qual a oferenda mudava.

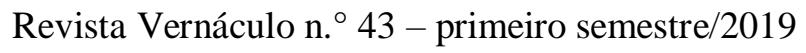

ISSN 2317-4021 
Perseguição". Os cristãos perderam desde terras até postos dentro do estado, foram ainda utilizados como sacríficos aos deuses; esse cenário permaneceu intenso por dois anos e só começou a mudar drasticamente a partir de 312 .

Segundo Brown, o protocolo da religião romana é quebrado logo após a batalha da ponte Milvio, do imperador Constantino contra seu rival Maxêncio, pois como de costume, em celebração vitória estavam todos reunidos no Capitólio para adorar a Júpiter, mas ao invés disso o imperador havia se dirigido ao palácio imperial e mais tarde faz saber sobre o in hoc signo vinces, o sonho as vésperas da batalha. Podemos afirmar que Veyne ${ }^{30}$ vai contrapor Brown, dizendo que é impossível dizer se o Imperador submeteu ou não ao costume ancestral dos generais vencedores.

\section{O sonho que mudou a História}

Constantino fue advertido en sueños para que grabase en los escudos el signo celeste de Dios y entablase de este modo la batalla. Pone en práctica lo que se le había ordenado $\mathrm{y}$, haciendo girar la letra $\mathrm{X}$ con su extremidad superior curvada en círculo, graba el nombre de Cristo en los escudos. ${ }^{31}$

O fato narrado por Lactâncio é claro, um sonho mudaria a história, as vésperas da batalha contra Maxêncio, Constantino recebe

${ }^{30}$ VEYNE, P. Quando o nosso mundo se tornou cristão: (312-394). Rio de Janeiro: Civilização Brasileira, 2010, p.125.

${ }^{31}$ LACTÂNCIO. Sobre la muerte de los perseguidores. Madrid: Editorial Gredos, 2000, p.189-190.

Revista Vernáculo n. ${ }^{\circ} 43$ - primeiro semestre/2019

ISSN 2317-4021 
uma "profecia" é o sinal visto no céu, seria o monograma ( $\mathrm{R}$ ), que até hoje representa a cruz de Jesus. Não é questão de acreditar que Constantino teve fé ou se realmente ele teve esse sonho, mas de compreender que tanto Lactâncio quanto Eusébio narram o mesmo e ambos afirmam que o imperador usou o "X" e o "P" (chi e ro, iniciais

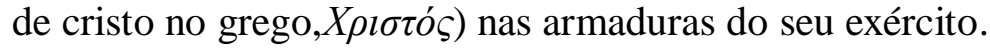

Constantino é a peça fundamental para a christianitas, mas ele não é o criador do cristianismo, nem o criador da igreja.Constantino não surge do nada e também a igreja não nasce com ele, para Peter Brown, ele é o resultado de um longo processo, para Veyne ele é o salvador da humanidade. Enquanto para o primeiro ele é figura principal para entender o processo, para o segundo “[...] na história do triunfo do cristianismo, o nome marcante não foi o de Constantino, o Grande, mas o de seu sucessor, o amargo e devoto Constâncio 11."32

Constantino, mais reservado, longe de empreender a conversão do Império ao cristianismo, fazendo deste uma religião estatal, dividiu a questão em duas vertentes: na esfera pública, optou pela tolerância e, na privada, escolheu o cristianismo como a religião pessoal do príncipe - que, como tal, tinha direito aos mais abundantes favores, privilégios e liberalidades financeiras. ${ }^{33}$

Veyne e Brown concordam que Constantino contribuiu grandemente para que o cristianismo viesse torna-se a religião oficial do Império 68 anos mais tarde. Além de colocar paz na igreja, o imperador

32 VEYNE, P. O Império Greco-Romano. Rio de Janeiro. Campus Elsevier, 2009, p.22.

${ }^{33} I d$,.Ibid., p.21-22.

Revista Vernáculo n. ${ }^{\circ} 43$ - primeiro semestre/2019

ISSN 2317-4021 
também ajudou com construções de basílicas em Roma como a de São Pedro e de São João do Latrão e a igreja do Santo Sepulcro em Jerusalém. Ao contrário do que alguns têm como imaginário, essas construções não eram sozinhas, mas sim anexados a sala de audiências, palácio episcopal extenso além de armazéns com alimentos para os pobres.

Como foi dito, para Veyneé importante ressaltar que quando Constantino assume o poder, o cristianismo não é uma religião tão nova, pois já existia cerca de duzentos e cinquenta anos, o que difere ela das demais religiões é o fato da igreja possuir um código compacto e fácil de transportar, enquanto a base da adoração a deuses era ligada a memória local.

A igreja a que Constantino trouxe a paz em 312 era já um corpo bastante complexo. É impossível saber quantos cristãos havia no Império desta época: já se sugeriu um máximo de 10 por cento da população, com uma concentração maior na Síria, na Ásia Menor e nas principais cidades do Mediterrâneo romano. O que se sabe de certeza é que não há qualquer justificação para o mito romântico que se desenvolveu mais tarde, segundo o qual os cristãos eram uma minoria perpetuamente perseguida, literalmente obrigada a clandestinamente pela severidade da repressão. E também não há qualquer fundamento para esse outro mito, mais moderno, que apresenta o avanço do Cristianismo como o desenvolvimento de uma religião dos menos favorecidos ${ }^{34}$.

${ }^{34}$ BROWN, Peter. A ascensão do Cristianismo no Ocidente. Lisboa: Editorial Presença, 1999, p.42-43.

Revista Vernáculo n. ${ }^{\circ} 43$ - primeiro semestre/2019

ISSN 2317-4021 
Com base na afirmação de Brown, é difícil precisar quantos cristãos habitavam na época, e se eram eternamente perseguidos vivendo nas escuras e que apenas os mais pobres adotavam essa religião, sendo praticamente impossível dizer que os cristãos eram totalmente inocentes em termos de riqueza, poder e uso de escravo. A principal marca da igreja era caracterizada pela grande variedade, o que independia de sexo ou classe, o grande e o pequeno estavam àmesma "altura" 35 , pois, ambos eram regidos por uma lei universal de um único Deus, essa abrangência da igreja favoreceu para seu enorme crescimento.

Todo cristão dizia abertamente aos não cristãos que o erro estava ligado a idolatria e ao poder dos demônios, o que realmente difere do estereótipo criado na atualidade é o fato de que nesse período as pessoas da igreja cristã não negavam a existência dos deuses pagãos, mas consideravam todos maus e capazes de manipulação. Com essas acusações dos cristãos sobre os não cristão começara intensa uma série de martírios, podemos dizer que esses "extermínios" iniciaram na figura de Estêvão ${ }^{36}$, e com o passar do tempo esse tipo de morte começou a ser

\footnotetext{
${ }^{35}$ No sentido de todos serem iguais perante o Deus Cristão, conforme a afirmativa de Paulo em Gálatas. "Não há judeu nem grego, não há escravo nem livre, não há homem nem mulher; pois todos vós sois um só em Cristo Jesus. E se vós sois de Cristo, então sois descendência de Abraão, herdeiros segundo a promessa" (Gl, 3, 28-29).

${ }^{36}$ A história de Estêvão aparece em Atos 6 e 7, da Bíblia cristã. Estêvão foi o primeiro mártir da Igreja. Após ser acusado de blasfêmia, Estêvão foi levado perante o Sinédrio, onde falsas testemunhas depuseram contra ele, o acusando de pregar contra a adoração no Templo e contra a Lei (At 6:13), sendo ele expulso da cidade, apedrejado e as testemunhas depuseram as suas capas aos pés de um homem chamado Saulo (que veio depois a se converter e ser chamado Paulo, de Tarso).
}

Revista Vernáculo n. ${ }^{\circ} 43$ - primeiro semestre/2019

ISSN 2317-4021 
visto com "bons" olhos entre os cristãos, pois era como um sinal de triunfo e o koimetérion ${ }^{37}$ local de descanso.

Uma morte ligada a esse contexto era sinal de salvação oferecido diretamente por Deus no próprio centro das cidades. A base encontravase na afirmativa de Paulo "Porque para mim o viver é Cristo, e o morrer é ganho", levaram até mesmo jovens sobre martírio com uso de ursos e leopardos a não abrirem a boca, o que Brown julga como um poder divino e incompreensível.

\section{Afastando-se do pecado}

Segundo Brown, os filósofos ${ }^{39}$ contribuíram para a formação da Christianitas, argumentando que o cristianismo era uma filosofia dada por Deus, e aquele que desejava ser tornar sábio e ter felicidade, o primeiro passo seria ouvir a voz de Deus. Esses mesmos filósofos mostraram pela intelectualidade o objetivo do logos ( $\lambda$ ó $\%$ s), justificando até mesmoa lógica do batismo, pois embora a sabedoria fosse fundamental, o combate da comunidade cristã estava ligado também ao "aniquilar" o passado ainda existente na pessoa, sendo necessário despir totalmente do velho homem para que toda a malícia fosse eliminada.

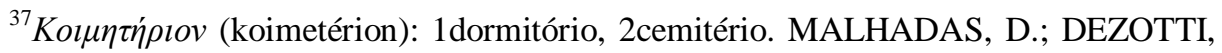
M. C. C.; NEVES, M. H. M. (coord.). Dicionário grego-português Vol. 3. Cotia: Ateliê Editorial. 2008, p. 80.

${ }^{38} \mathrm{Fl}, 1,21$.

${ }^{39}$ Como Justino, Clemente, Orígenes, Agostinho, etc.

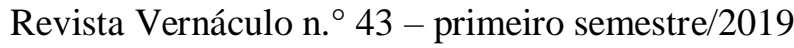

ISSN 2317-4021 
O afastar-se do pecado tinha tanta relevância que um agricultor de Fayum chamado Antônio (250-356), dirigiu-se ao deserto para ter uma vida de "santidade", o que acabou levando consigo algumas pessoas, as quais ficaram conhecidas como os Monachai "Homens Solitários" resumindo em si a figura da simplicidade de coração, retirando para uma vida no deserto homens erémos (eremitas) se afastando da vida 'mundana' e se tornando heróis e guias espirituais dos aldeões.

O pecado inconsciente era tratado de forma comum a todos os membros da comunidade cristã, e quando um necessitava de reparação todos intercediam em defesa perante Deus pelo indivíduo através da retidão, penitência e uma prática herdada do judaísmo, o dar esmolas pela remissão dos pecados.

\section{Christianitas em ação}

Com a moral estabelecida, sentimento de ajuda ao próximo e a liberdade no Império Romanoa Christianitas estava formada, a igreja recebia um grande apoio, a comunidade trabalhava em repressão ao pecado consciente, no entanto, outros ataques surgem ao sustentáculo da igreja, ou seja, a figura de Jesus. Podemos dizer que essa Christianitas que até então combatia fatores externos, agora tinha que repreender certas ideias divergentes do que era considerado como doutrina cristã, como por exemplo, as ideias pregadas por Ário (256 -

\footnotetext{
${ }^{40}$ Ver AMARAL, R. A Santidade habita o Deserto. A hagiografia à luz do imaginário social, São Paulo: Editora Unesp, 2009; também sobre a questão LACARRIËRE, J. Padres do Deserto, homens embriagados de Deus. Rio de Janeiro: Loyola, 1996.
}

Revista Vernáculo n. ${ }^{\circ} 43$ - primeiro semestre/2019

ISSN $2317-4021$ 
336), um presbítero cristão de Alexandria, fundador da doutrina, tida como herética pelo cristianismo histórico e ortodoxo, essa heresia denominada arianismo negava a divindade Jesus, dizendo que Ele era nada mais do que uma criatura, essas ideias começaram a propagar-se no meio dos povos, forçando assim a igreja a ter uma atitude.

Constantino em uma função de cesaropapismo, convoca no ano de 325 na cidade de Nicéia, um concilio ecumênico onde reuniu mais de 300 bispos. O concílio definiu a natureza divina de Jesus (Credo Niceno), a fixação da data da Páscoa (passou a ser diferente da Páscoa judaica) e a promulgação da lei canônica. Ficou definido também que o domingo seria o dia de descanso dos cristãos.

Brown faz questão de destacar a figura de Atanásio (296-373), como uma das figuras importante da ascensão do cristianismo, narrando como Constâncio II descreve-o, "Um homem que veio das camadas mais baixas da sociedade e que obteve autoridade... Os seus aduladores... aplaudiam, e muitos dos populares mais simples copiavam-no... O homem que dirigia a multidão não era diferente de um vulgar artesão"41. Foi ele a principal figura do Concílio e quem contribuiu para que a Igreja adotasse a doutrina da Trindade e a consubstancialidade do Pai com o Filho.

Essa Christianitas, já estava formada e atuando, inclusive condenando heresias, ganhando todo seu espaço no Império Romano,

${ }^{41}$ BROWN, Peter. A ascensão do Cristianismo no Ocidente. Lisboa: Editorial Presença, 1999, p. 58.

Revista Vernáculo n. ${ }^{\circ} 43$ - primeiro semestre/2019

ISSN 2317-4021 
no entanto, a religião romana começaria a cada vez mais ser pressionada para sua inexistência. No ano de 420 Isidoro de Pelúsia, um padre cristão, escreve "a religião dos gregos (pagãos), que dominou durante tantos anos, com tantos sofrimentos, um tão vasto desgaste de riqueza e tantos feitos de armas, desapareceu da face da terra."42 Constantino em um de seus primeiros éditos já havia dito que os pagãos poderiam continuar em sua ilusão, mas não poderiam forçar os cristãos a participarem dela, se o Imperador Constantino estava sendo duro em palavras, Constâncio II(337-361) e Teodósio I (379-395) foram mais intransigente nas ações e foram paulatinamente fechando os templos pagãos e terminando com sacrifícios públicos, até chegar na destruição do Serapeum de Alexandria no ano de 391.

Balsdon $^{43}$ traz uma ideia oposta a de Isidoro, afirmando que o paganismo não desapareceu da noite para o dia, grande parte dele tornase clandestina, como ainda permanece, tanto que no dia 25 de dezembro, o aniversário do Sol (Sol Invictus), passou a ser observado pela igreja cristã do século IV como o dia do nascimento do Criador do Sol; e quando, no Natal; as pessoas fazem a troca de presentes e usam um gorro de papel, na realidade, estão celebrando as Saturnálias.

Finalizando, é importante frisar que as identidades cristãs também se constituíram nas heresias (pelagianos, valdenses, albigenses, nestorianos, arianos, etc). Também salientamos que as disputas entre

${ }^{42} I d .$, Ibid., p.42-43.

${ }^{43}$ BALSDON J.P.V.D. O Mundo Romano.Rio de Janeiro: Zahar, 1968, p. 197.

Revista Vernáculo n. ${ }^{\circ} 43$ - primeiro semestre/2019

ISSN 2317-4021 
cristãos solidificaram a proposta da ortodoxia, como a Cláusula Filioque, TheótokosouChristótokos, iconoclastia ou iconodulia entre outros inúmeros embates.

\section{Considerações finais}

Para compreender todo esse processo citado no texto é necessário dois conceitos fundamentais, romanitas versus christianitas, sendo assim, exige algumas leituras mais aprofundadas sobre o assunto. Através desse artigo, buscamos demonstrar que antes de Constantino, os cristãos viviam em constante perseguição, onde ser romano era exatamente não ser cristão. Quando Constantino assume o poder esses ideais tem uma mudança de extrema significância, no século IV não há mais essa guerra declarada, onde de um lado se encontrar a romanidade e do outro a cristandade, no período citado ser romano é ser cristão, ou seja, a christanistas e romanitas andavam juntas.

Para entender as ações de Constantino utilizamos a fonte De Mortibus Persecutorum escrita por Lactâncio, que compreende entre os anos de 314/315, e até o ano da morte do imperador (337 d.C) Vita Constantini, escrito por Eusébio de Cesáreia. Essa ascensão do cristianismo no Império Romano ligado à figura do Imperador Constantino, terá efeito devido a esse longo processo, tanto que o povo que fazia sacrifícios até mesmo humano, não aceitaria o que estava sendo nupérrimo de imediato, mas sim paulatinamente. O século IV não é o momento em que todos os ideais cristãos nascem, mas podemos dizer que é quando os mesmo florescem, pois é nesse período que a 
christianitas ganhou força, e a partir desse momento tendeu só em aumentar o poder durante os períodos históricos.

\section{Referências}

BALSDON J.P.V.D. O Mundo Romano.Rio de Janeiro: Zahar, 1968.

Bíblia de Jerusalém. São Paulo: Paulus, 2002.

Bowman, A. K. Diocletian and the first tetrarchy, a.d. 284-305. In: The Cambridge Ancient History, The Crisis of Empire, a.d. 193-337. London: Cambridge University Press, 2008.

BROWN, Peter. A ascensão do Cristianismo no Ocidente. Lisboa: Editorial Presença, 1999.

BUENO, André. Etnografias religiosas no Livro das Leis dos Países, de Bardasano de Edessa. NEARCO - Revista Eletrônica de Antiguidade, Ano VIII, Número II, Rio de Janeiro, 2015

CESAREIA, Eusébio. Vida de Constantino. Madrid. Editorial Gredos, 1994.

CORNÉLIO TÁCITO.Annales. ed. Ch.D. Fisher, Oxford, Clarendon Press, 1906.

DANIEL-ROPS. A história da Igreja de Cristo I: A Igreja dos apóstolos e dos mártires. Porto: Livraria Tavares Martins, 1956.

ISIDORO DE SEVILHA.Etimologías. Edição bilíngue latim-castellano de OROZ RETA, J; MARCOS CASQUERO, M. A. Madrid: Biblioteca de Autores Cristianos, B.A.C., 2004.

JONES, A.H.M. A última crise: O Império romano até seu declínio. In BALSDON J.P.V.D. O Mundo Romano. Rio de Janeiro: Zahar, 1968.

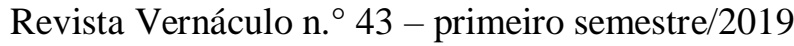

ISSN $2317-4021$ 
LACTÂNCIO. Sobre la muerte de los perseguidores. Madrid: Editorial Gredos, 2000.

MALHADAS, D.; DEZOTTI, M. C. C.; NEVES, M. H. M. (coord.). Dicionário grego-português Vol. 3. Cotia: Ateliê Editorial. 2006.

MOMIGLIANO, A. Il conflittotrapaganesimo e cristianesimonelsecolo IV. Roma: Einaudi, 1968.

MOMIGLIANO, A. Os limites da Helenização: a interação cultural das civilizações grega, romana, céltica, judaica e persa. Rio de Janeiro, Jorge Zahar Editor, 1991.

OLIVEIRA, W. F. A Antiguidade Tardia. São Paulo: Ática, 1990 TERTULIANO. Apologia. Trad. José Fernandes Vidal/ Luiz Fernando KarpsPasquotto. Disponível em: www.tertullian.org/brazilian/apologia.html, acesso dia 24/06/2017 ás 23:09.

VEYNE, P. Quando o nosso mundo se tornou cristão: (312-394). Rio de Janeiro: Civilização Brasileira, 2010.

VEYNE, Paul. Humanitas: Romanos e não-romanos. In: GIARDINA, Andréa. (Ed.). O Homem Romano. Tradução de Maria Jorge Vilar de Figueiredo. Lisboa: Estampa, 1992.

Recebido em 23/06/18 aceito para publicação em 18/01/19

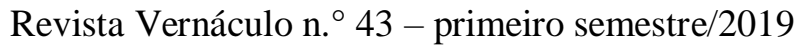

ISSN $2317-4021$ 